\title{
Review on Main Issues Causing Deterioration of Water Quality and Water Scarcity: Case Study of South Africa
}

\author{
Joseph Kapuku Bwapwa \\ Mangosuthu University of Technology, Engineering Faculty \\ P.O Box 12363, Jacobs 4026, Umlazi, Durban, South Africa \\ E-mail: josephkapuku@gmail.com
}

Received: December 10, 2017 Accepted: January 5, 2018 Published: May 18, 2018

doi:10.5296/emsd.v7i3.13156 URL: https://doi.org/10.5296/emsd.v7i3.13156

\begin{abstract}
Water shortage in South Africa is a mixture of many factors: limited and highly polluted watercourses, low rainfall, fast growing population and high evaporation rates. Many studies on watercourses have shown a decline on quality due to the ongoing pollution caused by urbanization, mining, industry, power generation, afforestation and agriculture. Given the current forecasts based on population growth versus the country's limited water resources, it is unlikely to keep existing patterns regarding the use of water and the discharge of wastes. Predictions are also indicating that pollutants will continue to accumulate in freshwater resources independently of the population growth in South Africa. Issues associated with water quality can turn out to be worsened with environmental devastating consequences. For instance, in the agricultural sector it may lead to a drop in yields and quality for fruits and crops followed by soil contamination. It can harmfully affect the population and aquatic health. Furthermore, water quality deterioration can affect the costs related to purification processes resulting in an increased price of clean water. Human induced activities causing salinization, eutrophication, acidification, presence of pathogens in watercourses, inappropriate waste discharge practices and sewage spills are major causes influencing or deteriorating water quality in South Africa.
\end{abstract}

Keywords: Eutrophication, Salinization, Water quality, Acidification, Water management, contaminants, Pollution

\section{Introduction}

South Africa is among the 30 driest countries in the world. Although it is indicated by various data from the South African weather services that some parts of the country have higher precipitations than others, the country has the lowest annual rainfall (450 $\mathrm{mm}$ per year) 
compared to the global average of $860 \mathrm{~mm}$ per year. South Africa has little non- polluted watercourses available and relies mostly on them and rainfall to supply water to the consumers. In this regard the country can be considered as a water-scarce country. Furthermore, issues such as water contamination and climate change may severely affect the limited quantity of freshwater resources accessible in the country. It well known that the availability of water resources is represented by an indicator known as water per capita. South Africa's water per capita is $1000 \mathrm{~m}^{3} /$ person/year, the comparison between South Africa and neighbouring countries shows that their available water per capita is greater than the South African's one. This is justified by the fact that neighbouring countries have water sources from higher rainfall sites and/or lower inhabitant areas. However, there could still be some hope for South Africa despite the alarming water scarcity situation and contamination of watercourses. Some simulations and models for water use, runoff and yield have predicted that there is enough water in the country for various needs in the near future (Bwapwa, 2015). This is confirmed by the facts that the country's annual runoff is approximately 43500 million $\mathrm{m}^{3}$ on average with the annual yield estimated at 13227 million $\mathrm{m}^{3}$ (DWAF, 2004a) However, these data are determined without taking into consideration the extent of contamination of many watercourses. It is very challenging to assess with exactitude the levels of contamination for all watercourses in the country. Therefore, to determine the amount of water use, the quantification of yield and runoff can also be a great challenge. Data generated in this situation can be based on approximations only. This is due to the complexity of the quality deterioration or contamination phenomenon taking place in various watercourses in the country (Bwapwa, 2015). The demand for clean water is growing due to the industrialisation, modernization and population growth. Scarcity and quality of water can be a huge problem but storage of water is not a challenge, the country has many options including reservoirs or lakes, boreholes, and the current dams. However, more dams still need to be built, the existing 569 dams with a capacity beyond 1 million $\mathrm{m}^{3}$ per unit, generating a total of 32400 million $\mathrm{m}^{3}$ of water, are not enough to sustain the country's needs. It is important to add the fact that big dams collect nearly $70 \%$ of the regular runoff on yearly basis (DWAF, 2004a). Also, many dam designs countrywide do not allow the discharge of sufficient water to meet the needs of the reserve; therefore, there is a need for more dams (Bwapwa, 2015). These facilities help secure enough water during low precipitation times and supply water to locations in high demand. Also, water resources may be stressed due to both the population and industrial growth. Agriculture, energy, industry and mining sectors have a real impact on water resources; the first one in securing food supply for the country and the others in supplying jobs and commodities for the growth of the economy. However, despite their positive impact, severe deterioration or contamination of water resources is recorded as a result of poor management of water resources (Bwapwa, 2015)

\section{Lower Water Quality and Environmental Consequences}

The need for clean water is more than a necessity in this $21^{\text {st }}$ century, for example the population health can be at risk if the quality of water used is very lower compared to the required standards. In terms of irrigation the yield and quality of the generated products will be affected if the quality of water is also very lower compared to the standards. Furthermore, 


\section{Macrothink}

Environmental Management and Sustainable Development

ISSN 2164-7682

2018, Vol. 7, No. 3

the soil surrounding various watercourses can be directly affected, especially if the water used for irrigation is polluted by pathogens and heavy metals. It is challenging to understand and analyse with accuracy the migration and diffusion facts of contaminants toward the soil, surface water and groundwater (Bwapwa,2015). Poor quality restricts water use and has an impact on purification costs. The more polluted is the stream, the higher the treatment costs for the removal of unwanted substances. The contamination of water streams in South Africa has reached a level at which even with no population growth the quality of water will still be deteriorated. Contaminants or pollutants will always accumulate in various water resources and their concentration may increase due the evaporation or continuous loading of waste into watercourses (Nansubuga et al., 2016). This is due to high level of industrialization, urbanization and lack of strict monitoring mechanisms to prevent discharging practises which are unlawful. Consequently, human and aquatic health may be adversely affected with the rising of waterborne diseases but also agriculture and many industries may also be affected because the yield and the quality of the final product will not be the same as it could have been with high quality raw water (Nansubuga et al., 2016; Oberholster and Ashton, 2008). It is also important to find a model that can allow an effective use of water to avoid overloading the carrying capacity of the natural system in South Africa. This will also prevent the decline of water quality to some extent.

\section{Water Use by Various Sectors in South Africa}

Irrigation is the biggest consumer of water in the country, it accounts for $62 \%$ of water use countrywide. Agriculture in many places in the world is generally the biggest user of fresh water resources, there is need to find an appropriate arrangement in order to optimize the use of freshwater for irrigation purposes. Therefore, an adaptation of water resources systems is important to change society and environment (Barrow, 2016; Thopil and Pouris 2016; Majuru et al., 2016; Saldías et al., 2016; Ceola et al., 2016). Urban and domestic sectors use $27 \%$, while mining and other industries account for $8 \%$, the remaining 3\% are used by commercial forestry plantations as represented in Figure 1 (DWAF, 2004a). It is imperative to ensure the quality of water is conformed to existing standards to prevent environmental related problems that can spread in all sectors of life. Water can run the economy of a country by providing food and energy and creating more employment opportunities (Woodhouse and Muller, 2017). 


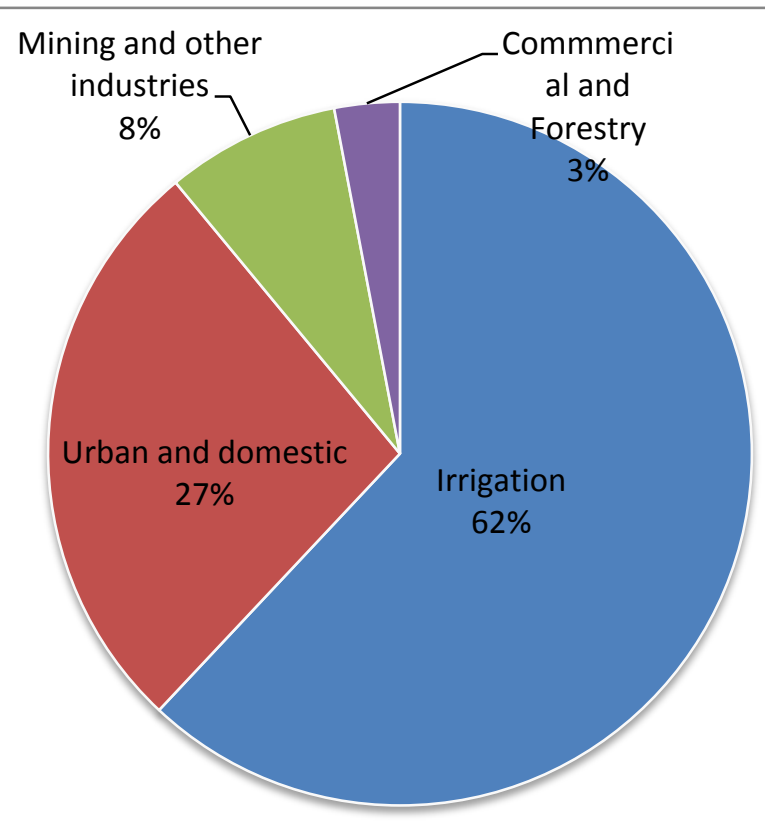

Figure 1. Water consumption by sector in South Africa (Bwapwa, 2015)

\section{Influence of Water Infrastructures and Management on Water Quality}

A large number of municipalities in the country are situated on areas of high altitude or upstream of many river catchments. In this situation, rivers have a double function: to supply water needed by consumers and also convey waste material or contaminants. Consequently, contamination of the water stored within the dams situated downstream and the surrounding soil have occurred for the last 10 years [Oberholster and Ashton (2008)]. It is important to emphasis on the fact that effluent discharged from urban, mining and agriculture infrastructures contribute greatly to deterioration of water quality in the country. To avoid contamination, measures should be taken to prevent a single contact between these effluents during discharge and freshwater resources by providing proper channelling systems. Also, large amounts of sewage from urban sites are not handled or processed correctly before discharge. Water quality is also very affected because of leakages, broken or incomplete parts in the sewer system including mismanagement and overloading of some sewage treatment plants. These plants are very old and need to be upgraded. Furthermore, solid wastes discharged in landfills may release materials that eventually leach into close water streams contributing to contamination [Oberholster and Ashton (2008)]. Unskilled labour operating in the plants is also another parameter that can influence water quality together with the outdated infrastructures as mentioned before (Rietveld et al., 2009; Snyman et al.,2006; Thopil, and Pouris, 2016). Objectively, there is a strong need for major changes regarding water quality management strategies and improvement of treatment technology and urban infrastructures. If no action is implemented, progressive deterioration of water quality will carry on with all the consequences mentioned before. Therefore, an aggressive approach in terms of water resources management and advanced low costs treatment technologies is needed to protect the available country's resources against pollution (Loucks and Van Beek, 
2017).

\section{Overview of Some Regions Affected by Water Scarcity}

Water shortage is already causing issues in many countries and affecting many sectors including agriculture and manufacturing. Each continent has a zone affected by drought and climate change which cause physical water scarcity. The increasing population and less water resources are worsening the situation of water scarcity.

Furthermore, water tables are falling in countries such as China, United States, Pakistan, Iran, Egypt, Algeria, Mexico and India. This will eventually lead to water scarcity or water crisis. Even with the over pumping of its aquifers, China is developing a grain deficit and it is predicted that the grain prices will increase in the next decade if the situation is not addressed properly. It is predicted that most of the 3 billion people projected to be added worldwide by mid-century will be born in countries already experiencing water shortages. Unless there is a way to slow down the population growth, it is feared that the emerging world water shortages can lead to conflicts in the future (Brown, 2002; Brown, 2006). The largest part of Australia is made of desert or semi-arid lands commonly known as the outback. Therefore, it is possible that there will be a long term, possibly irreversible, severe ecological damage in many parts of the world due to the situation of climate change and global warming. In Australia water restrictions are currently in place in many regions and cities of Australia in response to chronic shortages resulting from drought. There is also the Yemen situation for which the geographical position does not yield many fresh water resources. However, the current state of the country prevents these resources from reaching the hands that need it most. The Yemen's capital, Sanaa, is expected to be the first major city in the world to experience full water scarcity. Libya is another war-torn country dealing with major water-scarcity issues, water scarcity is not a priority because of the political upheaval. There is also Jordan located in one of the driest regions in the Middle East which is also becoming at risk country with high level of physical water scarcity. In this part of the world desalination of seawater is more developed and can be used to address the issue of water crisis or scarcity. Similarly, many countries that surround Jordan experience also water scarcity. Djibouti also deals with consistent droughts as it is in an arid, dry location, leaving several residents without any access to fresh water. In Pakistan, water scarcity is prevailing and the available resources are unceasingly on the decline. Agriculture is the largest consumer of freshwater and losses are very high as a result of mismanagement, provincial disputes, and conventional irrigation practices (Saeed et al., 2002; Pakistan Economic Survey, 2010). Briefly, water scarcity affects many parts of the world, the case of countries mentioned in this section reflects the extent and the potential threat of water scarcity worldwide. It is a serious issue that needs to be addressed quickly in order to avoid consequences that can affect the economy of many countries and cause crisis in sectors such as agriculture, food and manufacturing.

\section{Main Factors Affecting Water Quality and Scarcity in South Africa: Findings in South African Context}

Ongoing pollution caused by the industrialisation, urbanization and slow implementation of strict environmental regulations to prevent further contamination as mentioned earlier, has 
subsequently given birth to some key issues influencing directly the quality and scarcity in of water in many countries including South Africa (Byrne et al., 2016; Arenas-Sánchez et al., 2016; López-Gunn et al., 2016 ; Chen, 2016 ). These factors are salinization, eutrophication, acidification, pathogens, illegal waste discharge practices and sewage spills (Du Plessis, 2017).

\subsection{Salinization}

Salinization is a very challenging concern affecting the quality of water resources in the country for both groundwater and surface water. Rivers such as lower Vaal, the Breede, Crocodile and Olifants are known to be highly affected sites with high levels of recorded salinization in South Africa, furthermore, high salinization was recorded from the downstream of Bloemhof Dam to the confluence with the orange river (Van Rensburg et al., 2008) Concerning groundwater, nitrates found in many fertilizers used for agricultural activities are the main cause of high salinization in South Africa (Du Plessis, 2017). The main causes of salinization include also the following factors : return flows from irrigation with no proper quality monitoring, channelling systems, permanent contact between mine effluents and freshwater resources, leakages or overflowing of industrial polluted water into rivers and lakes, uncontrolled discharge of industrial and municipal effluents without complying to discharge standards and overflowing of storm water from urban activities and poorly managed rural and urban settlements (Vengosh, 2003). Solid wastes disposal from mineral processing or mining operations are also one of the threats to contamination of water resources which are close to these waste materials. They can spread easily toward freshwater resources especially during windy weather causing air pollution while contaminating water resources. The disposal and management of these types of waste need to be handle with care. Salinization is generated mostly by humans, to prevent it to occur it is indispensable to identify the probable point sources of pollution mostly at discharge points and to channel properly the contaminated sources by avoiding a contact between fresh water resources and polluted water (Du Plessis, 2017). The contact can occur by migration or diffusion of contaminants toward freshwater resources, migration or diffusion can be prevented by making an appropriate drainage system and regular monitoring of both polluted and non-polluted water resources (Vengosh, 2003). The drainage can be achieved by channelling polluted water into concrete drains or pipes or else pipes in steel for the transportation of contaminated water up to treatment plants or discharge sites. Salinization can cause corrosion and scaling, thus, piping systems in stainless steel or concrete are the most appropriate. Therefore, routine maintenance should be undertaken more regularly to prevent clogging, scaling even corrosion in the transportation or channelling system of contaminated water. Salinization has a negative impact on the yield and quality of the products in agriculture. It affects the treatment costs for low quality water with high salinity or total dissolved solids (TDS) because more substances need to be removed, therefore, more chemicals and supplementary processes will be needed for the removal by precipitation or separation when using membrane technologies (Bwapwa, 2015).

\subsection{Eutrophication}




\section{Mll Macrothink}

The accumulation of compounds deriving from nitrogen and phosphorus in water streams generates excessive algae species and aquatic plants, the process is called eutrophication. As many water streams in South Africa mostly rivers are very polluted, the country relying on rainwater and rivers to supply water to the consumers as mentioned before, eutrophication becomes a huge challenge that needs to be addressed to avoid deepening water crisis. Climatic conditions in the country due to climate change as well as treated and untreated effluent discharges have contributed to many and major shifts in aquatic ecosystems resulting in eutrophication of watercourses. Also, in agriculture excessive nutrient loads from return flows during irrigation have largely contributed to eutrophication of streams or watercourses. Sewage effluent discharged in water streams causes more eutrophication problems due to its high levels of nutrients (Oberholster et al., 2010; Du Plessis, 2017). The cyanobacteria Microcytis and Anabaena were found to be the most dominant algae species in most eutrophic watercourses around the country (Van Ginkel, 2004; Lemley et al., 2016). They generate some of the strongest toxins which can be harmful to aquatic and human life. Also, the toxic cyanobacteria known as blue-green algae cause many problems in water treatment because of the presence of toxic metabolites. The presence of cyanobacteria in municipal water includes extra costs for the removal of algal cells which may block filters. Microfiltration and ultrafiltration work better as polishing processes for the removal of the cyanobacteria after pre-treatment achieved through roughing or sand filtration. The consequences of eutrophication are very destructive for many watercourses, it is very important to prevent it by regular monitoring and control of discharges into water streams or watercourses (Lemley et al., 2016).

\subsection{Acidification of Watercourses}

Generally, most watercourses in South Africa have a stable $\mathrm{pH}$. The $\mathrm{pH}$ depends on environmental parameters such as the type of soil and the temperature. The main aspect involved in acidification of watercourses is human induced and uncontrolled actions. Some industrial and mining effluents more especially acid mine drainage (AMD), which are very acidic, are discharged into watercourses causing a drastic decrease of $\mathrm{pH}$. These effluents are coming from abandoned or defunct metallic or coal mines around the country. They are amongst the major causes for inducing acidification in watercourses. Acidification by AMD brings also other direct consequence : heavy metals such as lead, cobalt , ion, zinc , cadmium, nickel found in overflowing or decanting AMD effluents can be absorbed by the soil and finally being accumulated in plants and agricultural products such as fruits and vegetables(Oberholster et al.,2010).

It may cause major health related issues to the communities [USEPA, 1994; USEPA, 1999; Adler and Rascher, 2007; Du Plessis, 2017). AMD may contaminate groundwater especially when there is decanting, flooding or overflowing of AMD from abandoned mines, and then by diffusion or migration it can reach the aquifer and alter seriously the groundwater quality mostly the $\mathrm{pH}$. The contaminated groundwater discharged into various watercourses accounts for up to $20 \%$ of total stream discharge (CSIR, 2010).

Consequently, noticeable decrease of $\mathrm{pH}$ will be recorded; heavy metals that are not soluble 
at that $\mathrm{pH}$ can start precipitating. Acidification of watercourses or streams can be controlled with appropriate and decisive environmental risk management and strategies well implemented, followed by regular monitoring and law enforcement to prevent human induced actions.

\subsection{Presence of Pathogens in Water}

For any watercourse to be fit for use the pathogen load described by microbial characterisation is one of the major parameters to be considered. The issue of high pathogen loads in watercourses is mostly encountered in South African remote areas (peri-urban and rural areas) where e-coli and coliforms content have reached very high levels. In these areas problems related to inadequate sanitation, high population density, shortage of clean water, inappropriate waste removal practices and sewage spills may cause massive deterioration of water quality (NMMP, 2000; Hemson, 2016; Issaka and Ashraf 2017). Furthermore, the presence of faeces and urine discharged in many watercourses contribute greatly to this complex issue of high levels of pathogen loads into watercourses. Micro-organisms from these faeces and urine migrate easily by diffusion toward plants, fruits and vegetables through contaminated irrigation water. But also, the presence of faecal matter and urine in watercourses becomes a serious environmental threat for the population because of the associated potential health risks and the rise of waterborne diseases such as cholera, typhoid, diarrhoea and dysentery (Momba, 2004; Hemson, 2016; Du Plessis, 2017; Mutambara et al., 2016). Many rivers around the country are known as highest potential risk watercourses due to high levels of faecal contamination, some of them are: Elands river in Mpumalanga, Nsikazi river in Kwazulu- Natal, Buffels river in Eastern Cape, Olifants and Apies rivers in Gauteng. Best sanitation infrastructure, provision of clean water to unserved communities for domestic use and strong implementation of standard environmental practices as mentioned before can prevent this complex issue to happen.

\subsection{Illegal Solid Waste Discharge Practices}

Illegal dumping of solid wastes into watercourses is a common practice in the country and it is a great challenge for water authorities in most remote areas and districts where the population is using surface water for irrigation and domestic activities. In 1996 and in 2001 the outcomes of the census indicated that municipal wastes collection has improved greatly within the country; metropolitan municipalities which are larger compared to districts have achieved nearly $100 \%$ service. However, due to poor service delivery more than $50 \%$ of the population in the districts is not getting a regular municipal wastes collection service (DEA, 2010d; Du Plessis, 2017; Loucks and van Beek, 2017). This motive is sufficiently enough for illegal dumpers from remote areas to carry on with their activities. Consequently, illegal dumping of solid wastes into watercourses becomes preponderant compared to urban areas. These wastes are from various industries such as medical, manufacturing, chemical, pulp and textiles and mining industry. Their sizes vary from tiny particles of powder to blocks of big sizes. They can seriously affect the quality of watercourses more specially the turbidity, the physical appearance, the $\mathrm{pH}$ and give birth to the rise of unpleasant odours. They may contain harmful substances (organic or inorganic) that are soluble in water and are able to modify the 
quality of water once dissolved, and also insoluble substances that increase turbidity of watercourses ( FAO, 2008; Du Plessis, 2017 ). The motives behind illegal solid wastes dumping in water are many and they include the absence of collection services in some areas (rural and informal settlements mostly), the non-payment of landfill fees by the industry and the public, the absence of education regarding management and health implications of solids disposal, the absence of landfills close to affected areas and poor waste handling practices to name a few. Consequently, the dumping of solid wastes into watercourses that supply at the same time water for domestic uses and irrigation becomes the easiest way for the public to get rid of these wastes. It is indeed a vicious circle that requires a corrective waste management approach to eradicate this problem (Mutambara et al., 2016; Loucks and van Beek, 2017). It will be important to have landfills which meet legal requirements in many areas and to develop awareness campaign strategies about the danger of dumping solid wastes in watercourses. Jobs may be created for reuse, reclamation and recycling of wastes with new landfills.

\subsection{Sewage Spills}

Aging infrastructures used for transportation of sewage to its discharge point can also cause deterioration of water quality (Du Plessis, 2017). In this situation leakages of piping systems close to watercourses are not only the points of water losses but also, they also become contamination points. This happens mostly in remote areas where sewage spills end up by migrating to watercourses by diffusion toward reservoirs and boreholes (Momba et. al., 2004; Rieveld et al., 2009; Romanowicz, 2006). The situation is not regular but happens sometimes. The lack of adequate maintenance and regular monitoring of the piping systems are the major causes for contamination of sewage spills into watercourses. There is a necessity to revamp some of the water treatment infrastructures including the distribution channel to eradicate the risk affiliated with sewage spills contamination.

\subsection{Rapid Population Growth}

Rapid growth of population has a direct impact on water demand; the rate of population growth will impact on the available resources by depleting rapidly if no effective management strategy of the resources is not in place (Du Plessis, 2017; Loucks and van Beek, 2017; Chen, 2016; Butler and Memon, 2005). Population growth can result in greater volumes of polluted water. Generally, in developing countries, $90-95 \%$ of sewage and $70 \%$ of industrial waste are dumped into surface waters thus polluting the water supply (CSIR, 2010). Water quality is also affected by chemical run-off from pesticides and fertilisers and acid rain from air pollution, requiring expensive, energy-intensive processes to clean it for human use (Du Plessis, 2017).

\subsection{Industrialisation}

Remarkable industrialization of the country during the last decades supported by the presence of multinational and local companies in the mining, energy, manufacturing, food, finance, new information technologies and agriculture sectors has boost the country's economy ( $\mathrm{Du}$ Plessis, 2017). Despite the growth which is a bit stagnant with a challenge to create more jobs, 
South Africa is among the emergent countries in the world backed by very stable economy sustained by a strong and well established high rate of industrialisation on the African continent. Consequently, water demand has been increasing in relationship with the industrialisation growth (Du Plessis, 2017; Loucks and van Beek, 2017; Chen, 2016).

Water runs the economy of a country; all the sectors use it either for cleaning, drinking, washing, manufacturing or cooling (CSIR, 2010)

\subsection{Surface Runoff}

This also known as overland flow, it takes place from the excess of stormwater or overflow of other water courses over the ground surface. This occurs during flooding and many solid objects dissolve substances and sediments are brought into the source supplying freshwater to a community, therefore, the source of water supply becomes contaminated (Uitto and Biswas, 2000). Also, if the source is a river, this becomes a flooding source leaving the communities without water for basic and domestic uses. A proper planning for disaster management is needed to avoid this type of situations (Lévéque et al., 2006)

\subsection{Illegal Tap Connections}

This could be another human induced cause that hinders proper distribution of water to the communities. An illegal tap connection reduces the pressure of water and the volume of water expected by the end user. This can cause many consequences on day to day life in a community due to lack of enough water for domestic duties, even the manufacturing sector can be seriously affected (Sebola, 2000). The more illegal connections are being used the less water is received by the end user. Therefore, water becomes less and less available for the end user. The piping system needs to be set and installed in such a way that illegal connection cannot be possible.

\subsection{Poor Water Resource Management}

This is also one of the major causes of water scarcity which is directly linked to sewage spills, illegal solid waste discharge practices, surface runoff, acidification, salinization and pathogen presence in water resources. These factors are the direct consequences of poor water resource management. As water resources are becoming scarce due to many factors including rapid growing population, increasing human needs and industrialisation as mentioned earlier, this makes the effective management of the limited available water resources becoming very critical. South African water resources have poorly been management. This is aggravated by the geographic position of the country which is situated in the arid zone. This situation has impacted on the country's vulnerability to increasingly severe water shortages. Economically, water resources are a common-pool resource. This means that people have no incentive to save or use water efficiently. Therefore, effective management to deal with the externality of water use and market failure is needed. Over the past decades, Agriculture has been the greater consumer of water as mentioned earlier, despite the implementation of efficient strategies for water use the situation is far to be better. The institutional system of water resource management is ineffective. Water policies largely fail to account for the economic nature of water resources in relation to their natural characteristics. 


\section{Future Challenges to Affect Water Quality and Scarcity}

The rise of temperature from $2^{\circ} \mathrm{C}$ will likely cause evaporation in many watercourses countrywide in the near future (ACPC, 2011). As a result, concentration of pollutants or contaminants will increase and the volume of available water will decrease, this happens in many dams countrywide. Another consequence will be the acceleration of nitrification and rates of biological process. The rise of temperature is in correlation with global warming and climate change effects (ACPC, 2011; AMCE, 2009; Howard et al., 2016; Turton, 2016; Du Plessis, 2017; Pfeiffer and Hepburn, 2016). The north of Kwazulu-Natal (KZN) province has experiencing this challenge; dam levels have reached critical low levels during high temperature periods in the last 3 years. City of cape town has also been in the same situation with drought causing physical scarcity of fresh water resources. The rain is rare in the city, this is a direct consequence of drought. The best option to be undertaken to solve this problem can only be desalination of seawater. Saving strategies are not effective for a large city like cape town.

Mandatory restrictions in the distribution of water have already started in some municipalities in $\mathrm{KZN}$ in order to mitigate the risk to supply assurance in the short term. Water rationing is a level 4 water restriction measure (the highest). It has commenced at $30 \%$ restriction and depending on dam levels, it will be incrementally moved to $50 \%$ restriction. The second biggest challenge affecting water quality is acid mine drainage (AMD) when discharged into watercourses modifies severely the quality of water as mentioned before. Heavy metals and radioactive substances may increase the total dissolved solids content in watercourses. Consequently, the increase of the salinity and decrease of $\mathrm{pH}$ to acidic levels is recorded. Some soluble heavy metals locked up in the sediments are also being released in overlying water because of the low pH. (CSIR, 2010). AMD has many destructive and environmental consequences in many areas in the country at the present moment but also in the future (ERMITE Consortium, 2004a). There is a necessity to prevent this situation by developing management strategies that can prevent further disastrous consequences. Innovative treatment technologies together with good management practices can help tackle this issue. The volumes of AMD discharged per day in the country are very high, estimated in millions of litres per day. With good management practices and appropriate treatment technologies, AMD can be converted into clean water and may solve partially the problem of water scarcity in some affected areas in the country (ERMITE Consortium, 2004a; Turton, 2016; Chen, 2016). More studies should be undertaken in this regard

\section{Options to Tackle Water Scarcity in South Africa: Practical Solutions}

The following options are suggested in this study in order to reduce progressively or contribute toward the eradication of water scarcity faced in the country. These options could also be used in many other countries to help solve the water scarcity challenge (IDA, 2012).

\subsection{Water Restriction during Night Hours and Recycle-reuse Strategy}

Firstly, to deal effectively with water scarcity it is important to find ways of reducing consumption and optimizing the use of existing fresh resources (Jones, 2010; Camdessus, 
2012; Chenz, 2016).For instance, during night hours the supply system can be totally switched off, this is water restriction strategy, at night hours water use is lower than during day hours. The consumer will have to store as much as water needed for night hours. On domestic level, toilet flushing can use seawater mixed with AMD at neutral $\mathrm{pH}$ for areas close to the sea and mine exploration to reduce the consumption of fresh resources for toilet uses. The approach reuse-recycle which can still be undertaken because it is based on existing assets, however, it should be a precautionary measure because the more polluted is the fresh resource, the costly will be the treatment (Camdessus, 2012)

\subsection{Implementation of Strict Management Policies}

Strict management strategies can be undertaken as suggested earlier and supported by the awareness complain and saving strategies (UNDP, 2012). Also, a regular and consistent monitoring of water resources is necessary to assess the quality or level of pollution. However, the uncontrolled human behaviour mentioned earlier is still a big threat to pollution of freshwater resources. The illegal use and contamination of water should be eradicated systematically and the perpetrator should be charged for illegal use or purposeful contamination of water. Therefore, a complete identification of sites and areas where water is wasted or use illegally is important regarding saving strategy.

\subsection{Creation of More Catchment Sites and Use of Groundwater for Irrigation}

More catchment areas should be created wherever possible to have more water to help face with crisis times. The management and use of groundwater can also be explored because this can be another source of freshwater to add on the existing sources which are rivers and rainwater (Ashton et al., 2008). Groundwater can be a suitable approach for irrigation to reduce dependence of farmers on fresh available resources, as figure 1 shows that the biggest portion of fresh resources is taken by farming activities (Ashton et al., 2008). However, this approach needs more precautions measures especially in pollution prevention of groundwater with the use of fertilisers, more studies is needed to develop effective approaches in this area in preventing pollution and managing the groundwater resources.

\subsection{Desalination}

In the current situation it will be recommended to focus more on desalination processes which can help solve the scarcity problem (Naghizadeh, 2015; Kalavrouziotis et. al., 2015). Desalination has made progress in terms of low pressure and antifouling membranes, energy requirement for desalination has decreased considerably for the last decades, there is possibility to achieve desalination in South Africa. According to the international desalination association (IDA), currently 18426 plants are operating successfully worldwide with around 300 million of people using desalinated water for drinking and domestic uses in 150 countries. Relying on reuse -recycle strategy only is not very sustainable option nowadays due to a limited number of freshwater resources and the increasing demand and industrial growth that country has undergone for the last decades, therefore, desalination can be an option that can require some studies and adjustments but still can provide more than enough water to reduce the stress on available resources. The possible ways to use it is by technology transfer from 
successful countries and then readapt the technology to the South African context in terms of costs and implementation (Naghizadeh, 2015; Kalavrouziotis et. al., 2015). Another scheme will be to use desalination for farming activities; this will release a large amount of water. The option of treating acid mine drainage is also very important looking at the number of abandoned mines, AMD should be collected at specific sites, treated and reuse by farmers or manufacturing sector. Pipeline technology can be used to transport seawater to various farms with mobile desalination plants to supply desalinated water on farming sites. The quality of seawater from Atlantic and Indian oceans needs to be examined to determine which one is the most suitable for effective treatment coupled low energy requirements. The location of all farming activities throughout the country should be undertaken followed by the development of a distribution model system using pipeline technology. Seawater used on farming sites can be recycled by the movable plants keeping their autonomy in terms of water use (Naghizadeh, 2015; Kalavrouziotis et. al., 2015). Therefore, feasibility studies involving costs, energy and adequate logistics should be undertaken to analyse the possibilities and the success rate of this strategy. Thereafter, modelling studies to optimize the transport of seawater and the environmental assessment should be undertaken to be able to conclude if it is a viable option

\subsection{Use of Seawater for Toilet Flushing}

To reduce the consumption of freshwater used domestically, seawater can be used for flushing toilets, more water used domestically can be saved and used for other purposes

(Tang et. al., 2006; Youwei,2003). More studies need to be undertaken to optimize this strategy in order for it to be applicable. These studies will have to focus on the comparison between the existing network used for toilet flushing water in terms of its strengths, weaknesses, costs and the seawater network for toilets flushing (Youwei, 2003; UN-HABITAT, 2013). In fact, the same network can be used but only instead of freshwater seawater will be used. However, it will be more about an adaptive and modelling study in order to optimize to use seawater for toilet flushing; this adaptive study should also include the behaviour of network material with seawater (Tang et. al., 2006; Youwei, 2003). As a starting point, the mixture of freshwater and seawater for toilet flushing can be undertaken on a 1:1 ratio as a pilot project to examine the technico- economic as well as environmental aspects that can be involved in the implementation of this strategy and to decide if it can be beneficial at large scale (Tang et. al., 2006; Youwei, 2003).

\subsection{Rainwater Harvesting}

Already in use in some few places in the country and internationally, this strategy is also sustainable in terms of quality of harvested water (Helmreich and Horn, 2008). From its nature the quality of rainwater never cause problem for many uses including drinking purposes because does not contains pollutants, except in areas where the air is heavily contaminated from radioactive plants, petrochemical operation or mining and metallurgical processes (Helmreich and Horn, 2008). In these areas acid rain water is very frequent, drops of rain mighty be heavily contaminated. This approach can be useful for water saving because it can be done in communities individually per household or per manufacturing unit. (Mwenge et al., 2005; Mwenge et al., 2007) However, the strategy can be limited by the 
frequency of rainwater. In areas affected by drought this is not a sustainable strategy to be used for water savings (Mwenge et al., 2005)

\subsection{Depollution of Existing Water Courses}

Most rivers are highly polluted in the country which could be also a reality in many countries because the causes of pollution are mainly based on human behaviour as mentioned before (Chenje and Johnson 1996). The most realistic way for remediation of river pollution is through biological methods such as biotechnological processes due their low costs though in most cases they are passive treatment (Whitton and Kelly, 1995). Wetlands technology and algae biotechnology for contaminants intake can be among the most relevant options (Whitton and Kelly, 1995; Spiteri, 2016). However, to get acceptable results, this will require an effective approach and realistic methodology that can produce quality water from the depollution process (Jimenez-Cisneros, 2009; Spiteri, 2016). Therefore, studies on water quality for heavily polluted rivers or watercourses should be undertaken. Thereafter, trials for remediation can be undertaken depending on the type of contaminants found in various watercourses. This option is conceivable and achievable but it can be a long one and will require very skilled and big human resources and large financial resources (Jimenez-Cisneros, 2009). However, if it can be successful for some few selected watercourses, it will help solve to some extent the scarcity and remediate to pollution.

\section{Actions to Be Taken to Prevent an Imminent Crisis}

Water demand management needs to be solved by monitoring the way municipalities are dealing with the balance demand-supply (Butler and Memon 2005). The large municipalities known as metros are the bigger consumers of water because of their high level of industrialisation and population sizes. They are also causing water scarcity or deficit because of proper planning of water resources available. An intervention to compel the metros to involve more resources in terms of funds, research and manpower. Water theft is also another challenge the water sector has been facing, monitoring systems have to be put in place to prevent this situation especially in the Lesotho Highlands Water which is a vital Project that can help prevent water crisis. The energy supply for pump stations have to be provided effectively in order to have a continuous water supply. All sewage systems have to be subjected to a preventive maintenance program than a reactive maintenance which the case in many cases. This will avoid the sewers to be surcharged and reduce the risk of sewage spill in the potable water circuit. They have some progress in the water sector to manage the scarcity, however, there is need to prioritise regulations and policies and to put more emphasis on planning, capacity building and research to solve issues that can be preventing more progress in order to reduce the water scarcity challenges.

\section{Conclusion and Recommendation}

The increasing demand of clean water in many countries worldwide and particularly in a water-scarce country such as South Africa, requires the implementation of a radical management approaches, regular maintenance of water infrastructures as well as innovative treatment technologies for efficient remediation. It is found that in South Africa, salinization, 
eutrophication, acidification, presence of pathogens in watercourses, illegal dumping of solid wastes in watercourses are the major causes of worsening water quality. All of these are human induced causes; therefore, the protection of watercourses to prevent further pollution is possible and achievable. Methodical implementation and follow up of the existing strict environmental regulations including drastic changes where needed, can be the way forward to save water resources in a country where water supply is depending on rainfall and rivers which are already very polluted. The existing forecasts associated with patterns of global and climate change in South Africa, show that the rise of temperatures will contribute to the worsening of the water quality. Acid mine drainage(AMD) represents another major challenge that is severely affecting water quality currently and it may carry on in the near future because there is no effective way to stop pollution of watercourses cause by abandoned and defunct mines countrywide. Dams for storing AMD should be constructed beside each mining activity for catchment of AMD then followed by an appropriate treatment. AMD can be a great opportunity to get more freshwater after treatment due to the fact that large volumes AMD are being rejected in the environment without treatment. Treatment after storage in a dam can compensate the shortage due to high intake from agricultural activities. Treated AMD can be used for drinking and farming activities in the areas closed to the mines. Overall, water quality will always be subjected to deterioration unless strong actions with remedial management and innovative technologies are undertaken. The treatment technologies must be very efficient and low costs to be implemented proficiently. Therefore, with this approach it is possible to overcome the challenge of water quality deterioration in South Africa and many others countries in a similar situation. Also, there is a need to tackle the issue of water scarcity and contamination by using many strategies such as enforcement of policies and regular monitoring, rainwater harvesting, use of groundwater, seawater desalination, water restriction in some areas where the consumption is abusive, use of treated AMD and seawater for toilet flushing, creation and protection of catchment areas, depollution of freshwater resources affected by human induced behaviour. The combination of sustainable treatment technology and these strategies can be a milestone to overcome this challenge of scarcity and contamination regarding water resources. This approach can be applied in many counties around the world because the causes of scarcity and contamination of water resources are similar in many countries around the world. Briefly, to deal with scarcity saving strategies, reuse and reuse are the most important to deal with the scarcity. Other strategies can be used as second option unless there more innovative and affordable. For pollution, we need to educate the population about the necessity of not polluting freshwater resources. Policies on strict management are back strategy to protect water resources but education is more powerful.

\section{Recommendations}

With regard to the situation of critical water scarcity, the following is recommended

- Water restriction during night hours and recycle-reuse strategy

- Use of seawater for toilet flushing to reduce the stress on fresh water resources

- Desalination of seawater

- Rainwater harvesting 
- Depollution of existing water courses

- Appropriate water management practices and implementation or reinforcement of strict management policies

- Creation of more catchment sites and use of groundwater for irrigation

\section{Acknowledgments}

Thanking the research directorate for the support and encouragement.

\section{References}

Adler, R., \& Rascher, J. (2007). A strategy for the management of acid mine drainage from gold mines in Gauteng. Report CSIR/NRE/PW/ ER/2007/0053/C. Council for Scientific and Industrial Research: Pretoria, South Africa.

African Climate Policy Centre (ACPC), Climate Change and Water in Africa: Analysis of Knowledge Gaps and Needs. United Nations Economic Commission for Africa: working paper 4, November 2011.

African Ministerial Conference on the Environment (AMCE). Fact sheet: Climate Change in Africa, What is at Stake? AMCEN Secretariat: 2009.

Arenas-Sánchez, A., Rico, A., \& Vighi, M. (2016). Effects of water scarcity and chemical pollution in aquatic ecosystems: State of the art. Science of The Total Environment, 572, 390-403 https://doi.org/10.1016/j.scitotenv.2016.07.211

Ashton, P. J., Hardwick, D., \& Breen, C. M. (2008). Changes in water availability and demand within South Africa's shared river basins as determinants of regional social-ecological resilience. (In Burns, M.J. \& Weaver, A. (eds.) Exploring sustainability science: A Southern African perspective. Stellenbosch University Press: Stellenbosch, South Africa. p. 279-310.

Barrow, C. J. (2016). Water resources and agricultural development in the tropics. Routledge Brown, Lester R. (8 September 2002) Water Shortages May Cause Food Shortages. Greatlakesdirectory.org

Brown, L. R. (27 September 2006). Water Scarcity Crossing National Borders. Earth Policy Institute. Archived from the original on 2009-03-31

Butler, D., \& Memon, F. A. eds. (2005). Water demand management. IWA Publishing.

Byrne, J. A., Fernández-Ibá-ez, P., \& Sharma, P. K. (2016). 9 Water Scarcity in Developing Regions. Sustainable Water Management

Bwapwa, J. K. (2015). Investigation and analysis on key issues deteriorating water quality in a water-scarce country: Case of South Africa, Michigan state university, USA, September 2015, International conference on natural resources management

Camdessus, M. (2012). How to Beat Africa's Water Crisis. CNN, August 23. Global Public Square.

Ceola, S., Montanari, A., Krueger, T., Dyer, F., Kreibich, H., Westerberg, I., Carr, G., Cudennec, C., Elshorbagy, A., Savenije, H., \&Van Der Zaag, P. (2016). Adaptation of water resources 
systems to changing society and environment: a statement by the International Association of Hydrological Sciences. Hydrological Sciences Journal, 61(16), 2803-2817.

https://doi.org/10.1080/02626667.2016.1230674

Chen, Z. (2016). Water Shortages. Urban Water Reuse Handbook, p.1.

Chenje, M., \& Johnson, P. (1996). Water in southern Africa.

CSIR (Council for Scientific and Industrial Research) report (2010), A CSIR perspective on water in South Africa, Pretoria, South Africa

DEA (2010d) General Waste, State of the Environment, Department of Environmental Affairs, http://soer.deat.gov.za/369.html, (Downloaded, June 2015)

Du Plessis, A. (2017). Global Water Quality Challenges. In Freshwater Challenges of South Africa and its Upper Vaal River (pp. 13-44). Springer International Publishing. https://doi.org/10.1007/978-3-319-49502-6_2

DWAF (Department of Water Affairs and Forestry). (2004a). National water resource strategy. First edition. September 2004. Department of Water Affairs and Forestry: Pretoria, South Africa.

ERMITE Consortium. (2004a). Mining impacts on the fresh water environment: technical and managerial guidelines for catchment scale management. (In Younger, P.L. and Wolkersdorfer, C. (eds.), Mine water and the environment, 23A: S2-S80.)

Food and Agriculture Organization (FAO). (2008). Water for agriculture in Africa: Resources and challenges in the context of climate change. Ministerial conference on water for agriculture and energy in Africa: The challenges of climate change, Sirte, Libyan Arab Jamahiriya, 15-17 December 2008.

Helmreich, B., \& Horn, H. (2008). Opportunities in rainwater harvesting, Desalination, 248(2009), 118-124. https://doi.org/10.1016/j.desal.2008.05.046

Hemson, D., (2016). Water, sanitation and health: South Africa's remaining and existing issues. South African Health Review, 1, 25-34.

Howard, G., Calow, R., Macdonald, A., \& Bartram, J. (2016). Climate change and water and sanitation: likely impacts and emerging trends for action. Annual Review of Environment and Resources, 41, 253-276. https://doi.org/10.1146/annurev-environ-110615-085856

International Decade for Action (IDA) (2012). 'Water For Life' 2005-2015. Gender and Water, Human Right to Water, Water and Cities, and Water Scarcity. Focus Areas: United Nations Department of Economic and Social Affairs, 2012.

Issaka, S., \& Ashraf, M. A. (2017). Impact of soil erosion and degradation on water quality: a review. Geology, Ecology, and Landscapes, 1-11.

https://doi.org/10.1080/24749508.2017.1301053

IDA, International Desalination Association, http://idadesal.org/desalination-101/ accessed in 
March 2016

Jimenez-Cisneros, B. (2009). Coming to terms with nature: water reuse new paradigm towards integrated water resources management. Future Challenges of Providing High-Quality Water, I, 195

Jones, D. (2010). The Threat of a Global Water Shortage. US Infrastructure, January 7, 2010.

Kalavrouziotis, I. K., Kokkinos, P., Oron, G., Fatone, F., Bolzonella, D., Vatyliotou, M., Fatta-Kassinos, D., Koukoulakis, P. H., Varnavash, S. P., Madani, M., \& Aliabadi, M., (2015). Desalination and Water Treatment. SCIENCE AND ENGINEERING, 53(8).

Lemley, D. A., Adams, J. B., \& Bate, G. C. (2016). A review of microalgae as indicators in South African estuaries. South African Journal of Botany, 107, 12-20.

https://doi.org/10.1016/j.sajb.2016.04.008

Lévéque, C., Naiman, R. J., Prieur-Richard, A., Soto, D., Stiassny, M. L. J., \& Sullivan, C. A. (2006). Freshwater biodiversity: Importance, threats, status and conservation challenges. Biological Reviews, 81, 163-182. https://doi.org/10.1017/S1464793105006950

López-Gunn, E., Ballesteros, M., De Stefano, L., Garrido, A., Hernández-Mora, N., \& Willaarts, B. A. (2016). Water security or water 'securities'? Increasing complexity in balancing of multiple goals in Spain. Handbook on Water Security, p.257.

https://doi.org/10.4337/9781782548010.00024

Loucks, D. P., \& van Beek, E. (2017). Water resources planning and management: An overview. In Water Resource Systems Planning and Management (pp. 1-49). Springer International Publishing. https://doi.org/10.1007/978-3-319-44234-1_1

Majuru, B., Suhrcke, M., \& Hunter, P. R. (2016). How Do Households Respond to Unreliable Water Supplies? A Systematic Review. International Journal of Environmental Research and Public Health, 13(12), 1222. https://doi.org/10.3390/ijerph13121222

Momba, M. N. B., Tyafa, Z., \& Makala, N. (2004). Rural water treatment plants fail to provide potable water to their consumers: the Alice water treatment plant in the Eastern Cape Province of South Africa. South African Journal of Science, 100, 307-310.

Mutambara, S., Darkoh, M. B., \& Atlhopheng, J. R. (2016). A comparative review of water management sustainability challenges in smallholder irrigation schemes in Africa and Asia. Agricultural Water Management, 171, 63-72. https://doi.org/10.1016/j.agwat.2016.03.010

Mwenge, K., Boroto, J. R., \& Taigbenu, A. E., (2005). Developing and integrating water resources management and rainwater harvesting systems in South Africa, in: Proceedings of the 12th SANCIAHS Symposium, Johannesburg, South Africa

Mwenge, K., Taigbenu A. E., \& Boroto, J. R. (2007). Domestic rainwater harvesting to improve water supply in rural South Africa. Phys. Chem. Earth, 32, 1050-1057.

https://doi.org/10.1016/j.pce.2007.07.007

Naghizadeh, A., Nasseri, S., Mahvi, A. H., Rashidi, A., \& Nabizadeh, R. (2015). Desalination 
and Water Treatment. Optimization, 54, 9.

Nansubuga, I., Banadda, N., Verstraete, W., \& Rabaey, K. (2016). A review of sustainable sanitation systems in Africa. Reviews in Environmental Science and Bio/Technology, 15(3), 465-478. https://doi.org/10.1007/s11157-016-9400-3

NMMP (National Microbial Water Quality Monitoring Programme). (2000). Identification and prioritisation of areas in South Africa with a potentially high health risk due to faecally polluted surface water. DWAF Report N/0000/00/ EE/Q/4399. Department of Water Affairs Forestry: Pretoria, South Africa.

Oberholster, P. J., \& Ashton, P. J. (2008). State of the nation: An overview of the current status of water quality and eutrophication in South African rivers and reservoirs. CSIR Report No. CSIR/NRE/WR/IR/2008/0075/C. Council for Scientific and Industrial Research: Pretoria, South Africa. p. 14

Oberholster, P. J., Myburgh, J. G., Ashton, P. J., \& Botha, A-M. (2010). Responses of phytoplankton upon exposure to a mixture of acid mine drainage and high levels of nutrient pollution in Lake Loskop, South Africa. Ecotoxicology and Environmental Safety, 73, 326-335. https://doi.org/10.1016/j.ecoenv.2009.08.011

Oberholster, P. J., Botha, A-M., \& Cloete, T. E. (2008). Biological and chemical evaluation of sewage water pollution in the Rietvlei Nature Reserve wetland area South Africa. Environmental Pollution, 156, 184-192. https://doi.org/10.1016/j.envpol.2007.12.028

Pakistan Economic Survey, (2010). 2009-10 Survey, Finance Division, Islamabad, Pakistan. Printing Corporation, Pakistan Press.

Pfeiffer, A., \& Hepburn, C., (2016). Facing the Challenge of Climate Change. Global Journal of Emerging Market Economies, 8(2), 201-215. https://doi.org/10.1177/0974910116634473

Rietveld, L. C., Haarhof, J., \&Jagals, J. (2009). A tool for technical assessment of rural water supply systems in South Africa. Physics and Chemistry of the Earth, 34, 43-49. https://doi.org/10.1016/j.pce.2007.12.001

Romanowicz, G., (2006). Raw Sewage Polluting South Africa's Drinking Water. Edie Waste, March 21, 2006.

Saldías, C., Speelman, S., van Koppen, B., \& Van Huylenbroeck, G., (2016). Institutional arrangements for the use of treated effluent in irrigation, Western Cape, South Africa. International Journal of Water Resources Development, 32(2), 203-218.

https://doi.org/10.1080/07900627.2015.1045970

Snyman, H. G., Van Niekerk, A. M., \& Rajasakran, N. (2006). Sustainable wastewater treatment - What has gone wrong and how do we get back on track. Proceedings of the Water Institute of South Africa (WISA) Conference, Durban, 21-25 May 2006.)

Spiteri, C., Roddier-Quefelec, C., Giraud, J. P., \& Hema, T. (2016). Assessing the progress in depolluting the Mediterranean Sea. Marine pollution bulletin, 102(2), 295-308. 
https://doi.org/10.1016/j.marpolbul.2015.08.009

UN-HABITAT (2013). Water and Sanitation. Programmes: Water and Sanitation, 2013.

United Nations Development Program (UNDP) (2012). Water and Ocean Governance. Environment and Energy: focus areas.

USEPA (United States Environmental Protection Agency) (1994). Acid mine drainage prediction. Office of Solid Waste. United States Environmental Protection Agency: Washington, DC, USA.

USEPA (United States Environmental Protection Agency) (1999). Health effects from exposure to sulphate in drinking water workshop. EPA 815-R-99-002. Office of Water. United States Environmental Protection Agency: Washington, DC, USA.

Van Rensburg, L. D., Strydom, M. G., Du Preez, C. C., Bennie, A. T. P., Le Roux, P. A. L., \& Pretorius, J. P. (2008). Prediction of salt balances in irrigated soils along the lower Vaal River, South Africa. Water SA, 34, 11-17

Van Ginkel, C. E. (2004). A national survey of the incidence of cyanobacterial blooms and toxin production in major impoundments. Internal Report No.N/0000/00/DEQ/0503. Resource Quality Services, Department of Water Affairs and Forestry: Pretoria, South Africa. p44.

Vengosh, A. (2003). Salinization and saline environments. Treatise on geochemistry, 9, 333-365. https://doi.org/10.1016/B0-08-043751-6/09051-4

Youwei, C., Guohui, Z., Liping, J., Shuying, W., \& Yongzhen, P. (2003). Feasibility research on biological treatment of sewage resulting from using seawater for flushing toilets. Industrial Water Treatment-tianjin, 23(12), 33-36.

Uitto, I., \& Biswas, A. K. (2000). Water for Urban Areas: Challenges and perspective. United Nations University, New York.

Saeed, M., Ashrif, M., \& Bruen, M. (2002). Diagnostic analysis of framers skimming well technologies in the Indus Basin of Pakistan. Irrig. Drain Sys., 16, 139160.

https://doi.org/10.1023/A:1016032604711

Sebola, M. P. (2000). The water supply schemes, scarcity and development projects. A case of Taaiboschgroet, Northern Province. Masters dissertation, University of Limpopo.

Tang, S. L., Yue, D. P. T., \& Li, X. Z. (2006), Comparison of engineering costs of raw freshwater, reclaimed water and seawater for toilet flushing in Hong Kong. Water and Environment Journal, 20, 240-247. https://doi.org/10.1111/j.1747-6593.2006.00036.x

Thopil, G. A., \& Pouris, A. (2016). A 20 year forecast of water usage in electricity generation for South Africa amidst water scarce conditions. Renewable and Sustainable Energy Reviews, 62, 1106-1121.https://doi.org/10.1016/j.rser.2016.05.003

Turton, A. (2016). South Africa and the drought that exposed a young democracy. Water 


\section{Macrothink \\ Environmental Management and Sustainable Development \\ ISSN 2164-7682 \\ 2018, Vol. 7, No. 3}

Policy, 18(S2), 210-227. https://doi.org/10.2166/wp.2016.020

WHITTON, B. A., \& KELLY, M. G. (1995). Use of algae and other plants for monitoring rivers. Austral Ecology, 20(1), 45-56. https://doi.org/10.1111/j.1442-9993.1995.tb00521.x

Woodhouse, P., \& Muller, M. (2017). Water Governance; an Historical Perspective on Current Debates. World Development. https://doi.org/10.1016/j.worlddev.2016.11.014

\section{Copyright Disclaimer}

Copyright for this article is retained by the author(s), with first publication rights granted to the journal.

This is an open-access article distributed under the terms and conditions of the Creative Commons Attribution license (http://creativecommons.org/licenses/by/3.0/). 